\title{
Effects of Drying Parameters on Dehydration of Green Banana (Musa sepientum) and its Use in Potato (Solanum tuberosum) Chips Formulation
}

\author{
M. S. Islam ${ }^{1}$, M. A. Haque ${ }^{2}$ and M. N. Islam ${ }^{1}$ \\ ${ }^{I}$ Department of Food Technology and Rural Industries, Bangladesh Agricultural University, \\ Mymensingh-2202, Bangladesh \\ ${ }^{2}$ Department of Agro-processing, Bangabandhu Shaikh Mujibur Rahman Agricultural University, \\ Gazipur-1706, Bangladesh
}

*Corresponding author and Email: amdadhstu@yahoo.com

Received: 6 March 2012

Accepted: 26 May 2012

\begin{abstract}
The present study quantifies the drying kinetics of green banana during mechanical dehydration. The effect of loading density (sample thickness) and the temperature on the drying rate constant and drying time were investigated and quantified. Drying rate increased with increasing temperature but decreased with increase in loading density. The values of exponent ' $n$ ' of the two parameters power law model describing the drying rate constant (as a function of thickness) were less than 2 which indicated the presence of significant external resistance to mass transfer despite the dominance of internal mass transfer resistance. Investigation with three drying air temperatures $\left(55,60\right.$ and $\left.65^{\circ} \mathrm{C}\right)$ at constant air velocity $(0.6 \mathrm{~m} / \mathrm{sec})$ resulted that the increase in drying air temperature increased the drying process. The moisture diffusivity values were $1.25 \times 10^{-10}, 1.67 \times 10^{-10}$ and $2.19 \times 10^{-10} \mathrm{~m}^{2} / \mathrm{sec}$ at 55,60 and $65^{\circ} \mathrm{C}$ respectively. The activation energy $\left(\mathrm{E}_{\mathrm{a}}\right)$ indicating the temperature dependence of the diffusivity was $51.21 \mathrm{KJ} / \mathrm{mole}$ obtained using Arrhenius model. Mixing of green banana flour in the potato chips formulation enhanced the fiber and mineral content in the product.
\end{abstract}

Keywords: Drying rate constant, moisture diffusivity, drying kinetics, loading density, activation energy

\section{Introduction}

The word "banana" is a general term embracing a number of species or hybrids in the genus Musa of the family Musaceae. Bananas and plantains (cultivars of banana having firmer and starchier fruit) are grown today in every humid tropical region and constitute the second largest fruit crop following the citrus fruits of the world (Haque, 2008). Due to its perishable nature the banana cannot be preserved more than 7 days at room temperature $\left(20^{\circ} \mathrm{C}\right)$ from the initiation of ripening (Farid, 2003). About one fifth of the harvested bananas is spoiled or rejected (Choo,
2007). In order to increase the utilization of culled banana, some researchers have suggested converting the green banana into flour and starch (Suntharalingam and Ravindran, 1993).

Conventional air-drying is the most frequently used dehydration operation in food and chemical industry and as such preferably used in drying of banana and banana chips. In this case, the drying kinetic is greatly affected by air conditions (air temperature, air humidity and air velocity) and material properties (including the characteristic dimension), while other process factors exert negligible influence (Krokida et al., 2003; 
Kiranoudis et al., 1997). Hence, optimization of the drying operations must minimize the consumption of energy and minimize the processing effect on the biologic quality of the dried products (Belghit et al., 2000). The optimization of drying parameters of mechanical dryer also leads to the increased production rate of dried products (Ibrahim et al., 2009).

Apart from consumption of fresh banana, they can be processed or semi-processed into various tasty items such as fruit cups and salads, sandwiches, custards and gelatins etc. Green bananas are generally consumed as vegetable and banana chips from green banana slices. Despite its nutritional value and economic potential, banana flour is not listed in the common food items produced from banana. It is hardly seen as consumer product in the international food market (Haque, 2008). About $32 \%$ of banana's total production is harvested as green banana (FAO, 2003), which is rich in carbohydrate especially starch (20-25\%) (Cordenunsi and Lajolo, 1995), dietary fiber especially hemi cellulose $(6.08 \%)$ (Kayisu et al., 1981), essential minerals such as potassium, phosphorus and calcium and various vitamins such as $\mathrm{A}, \mathrm{B}_{1}, \mathrm{~B}_{2}$ and $\mathrm{C}$ (Morton, 1987). Besides, green banana has been found to reduce clinical severity of childhood Shigellosis and is useful in treating diarrheal diseases (Rabbani et al., 2009). In the green stage, for having high percentage of starch, banana is suited to be used as the source of starch and flour. Green banana flour can be a healthier replacement of wheat flour and potato flour. Despite good prospects and health benefits, green banana flour has not yet been fully utilized. The major reasons behind this under utilization may be higher cost associated with its conversion into flour (compared to other starch flours) and limited researches highlighting the potential and the beneficial properties (BelloPerez et al., 1999). Hence, the present research aimed at investigating drying behavior of green banana during mechanical dehydration together with assessing applicability of green banana flour in potato chips formulation.

\section{Materials and Methods}

\subsection{Materials and equipments}

Good quality green bananas (Musa sepientum), potato powder, starch, wheat powder and soybean oil were collected from the local market. A cabinet dryer (OV-165, Gallenkamp Company) was used for drying of banana slices. The velocity of drying air was kept constant at $0.6 \mathrm{~m} / \mathrm{sec}$. A temperature range of 55 to $65^{\circ} \mathrm{C}$ was used. Excessively high temperatures were not used to avoid the possibility of nutrient loss and of case hardening.

\subsection{Mechanical drying experiment}

Loading densities of 4,6 and $8 \mathrm{~kg} / \mathrm{m}^{2}$ of crushed banana (corresponding initial thickness were 5 , 7.5 and $10 \mathrm{~mm}$ respectively) were dried at $65^{\circ} \mathrm{C}$ to determine the effect of loading on the drying rate. To determine the effect of temperature on the drying rate, these slabs were dried at three different temperatures $\left(55,60\right.$ and $\left.65^{\circ} \mathrm{C}\right)$. The effect of thickness on drying rate was also investigated. The change of sample mass over time was recorded to calculate the drying rate constants, diffusion coefficients and values of exponent ' $n$ ' of the two parameters power law model. The temperature dependence of diffusion coefficient was determined which was used to determine activation energy for diffusion of water from green banana.

\subsection{Preparation of green banana flour}

After washing in clean water, each banana was cut into 3 to 4 pieces which were then blanched in boiled water for 5 minutes and peeled manually. Subsequently, they were sliced into 3 $\mathrm{mm}$ uniform pieces by a mechanical slicer. These sliced pieces were then dipped into $0.2 \%$ KMS solution for 10 minutes to enhance the color of the finished product. The slices were dried in a cabinet dryer for about 8 hours at $65^{\circ} \mathrm{C}$. Finally, the banana flour was obtained by grinding the dried banana pieces in a flour mill and packed in polyethylene bags for further use. Precaution was taken carefully to avoid any mixing with other materials during grinding and packaging. 


\subsection{Preparation of chips}

Five formulations of chips were prepared using five different ratios of potato and green banana powder. The ratios of potato powder and green banana powder were 70:30 (Type-111), 60:40 (Type-222), 50:50 (Type-333), 40:60 (Type444), and 30:70 (Type-555). A control sample without banana flour was also prepared. In each formulation of chips, $10 \%$ starch and $10 \%$ wheat flour were added to impart better crunchiness and crispiness.

The measured amounts of potato powder, green banana powder, starch and wheat flour were mixed and heated in water for 3 to 5 minutes to gelatinize the dough. Thereafter, salt at the rate of $1.5 \mathrm{~kg}$ per $100 \mathrm{~kg}$ of chips was added in the mix (Reddy and Das, 1993). Small amount of spices were added to improve the aesthetic value of the chips. The entire mix was finally blended using a blending machine (B50, Guangzhou China youjia Machinery Co.) to prepare the dough. Then the dough was spread out on a clean polyethylene paper and cut into $30 \times 25 \times 0.5 \mathrm{~mm}$ slabs. After drying at $65^{\circ} \mathrm{C}$ for 3 hours these slabs were fried in good quality soybean oil at $165^{\circ} \mathrm{C}$ for $2-3$ minutes in order to reduce the final moisture content to 2-3\% (Lewis et al., 1995). The resultant chips had appealing golden brown color.

\subsection{Chemical analysis}

Moisture, ash, fat, protein, total carbohydrate, crude fiber and vitamin $\mathrm{C}$ of the green banana flour, potato flour as well as chips were determined by the methods described by Rangana (1992). The calorie values of the samples were also determined by Bomb calorimeter.

\subsection{Analysis of the Experimental Data}

Fick's diffusion equations are commonly used to determine the effective diffusivity of moisture during food drying (Conway et al., 1983; Kaymak-ertekin and Cakaloz, 1996; Sablani et al., 2000). Hence the Fick's second law of diffusion was used here to analyse the experimental data, as given by equation (1).

$$
\frac{\delta M}{\delta t}=\nabla^{2} D_{e} M
$$

Where,

$\mathrm{M}=$ moisture content (dry basis)

$\mathrm{t}=$ time $(\mathrm{s})$

$D_{e}=$ effective diffusion coefficient $\left(\mathrm{m}^{2} / \mathrm{s}\right)$, which describes how fast an object diffuses.

$\nabla=$ Mass transfer gradient

To find a solution of the above unsteady state diffusion equation for one dimensional moisture transfer with uniform initial concentration and negligible external resistance appropriate boundary conditions were assumed. Assumption included the moisture content in the surrounding environment (bulk) did not change; there was negligible external resistance to moisture transfer compared to internal diffusion resistance. It was also assumed that there was negligible temperature gradient within the sample and negligible shrinkage during drying. It also assumed that the diffusion coefficient was constant at a specific temperature. The solution, previously reported by several researchers (Sogi et al., 2003; Roberts et al., 2008) for an infinite slab with thickness $\mathrm{L}$ when dried from one major face was:

$M R=\frac{M_{t}-M_{e}}{M_{o}-M_{e}}=\frac{8}{\pi^{2}} \sum_{n=0}^{\infty} \frac{1}{(2 n+1)^{2}} e\left(\frac{-(2 n+1)^{2} \pi^{2} D_{e} t}{L^{2}}\right)$

Where,

$M_{o}=$ initial moisture content

$M_{t}=$ moisture content at time, $\mathrm{t}$

$\mathrm{M}_{e}=$ equilibrium moisture content

$\mathrm{n}=$ order of equation

For low $M_{e}$ values and for moisture ratio $\mathrm{MR}<0.6$ equation ( 1$)$ reduced to: 
$M R=\frac{M_{t}}{M_{o}}=\frac{8}{\pi^{2}} e \frac{-\pi^{2} D_{e} t}{L^{2}}=\frac{8}{\pi^{2}} e^{-m t}$

Where, $m=\frac{\pi^{2}}{L^{2}} D_{e}=$ drying rate constant, sec ${ }^{-1}$

Therefore,

$M R=\frac{8}{\pi^{2}} e^{-m t}$

Rearranging equation (2a) gave:

$$
\begin{aligned}
& \ln \frac{M_{t}}{M_{o}}=\ln \frac{8}{\pi^{2}}-m t \\
& \ln M R=\ln \frac{8}{\pi^{2}}-m t
\end{aligned}
$$

A straight line was obtained when MR was plotted against time (t). Drying rate constant was the slope of the regression line from which the effective diffusion co-efficient $\left(D_{e}\right)$ was calculated.

The diffusion co-efficient, $\mathrm{D}_{\mathrm{e}}$ had an Arrhenius type of relationship with drying air-dry bulb temperature $\left(\mathrm{T}_{\mathrm{abs}}\right)$, which was used to describe temperature dependence of the diffusion coefficient. The relationship was as follows (Islam, 1980; Vaccarezza et al., 1974; Suarez et al.,1980):

$$
\frac{d \ln D_{e}}{d T_{a b s}}=\frac{E_{a}}{R T^{2}{ }_{a b s}}
$$

Or

$$
D_{e}=D_{o} e^{-E_{a} / R T_{a b s}}
$$

Where, $\mathrm{D}_{0}=$ the constant of integration and is usually referred to as a frequency factor when discussing Arrhenius equation, $\mathrm{m}^{2} / \mathrm{sec}$

$\mathrm{E}_{\mathrm{a}}=$ activation energy of diffusion of water, $\mathrm{KJ} / \mathrm{mole}$
$\mathrm{R}$ = gas constant, $\mathrm{KJ} /$ mole, ${ }^{\mathrm{o}} \mathrm{k}$

$\mathrm{T}_{\mathrm{abs}}=$ absolute temperature, ${ }^{\mathrm{o}} \mathrm{k}$

From equation (5) it can be seen that when diffusion co-efficient $\left(\mathrm{D}_{\mathrm{e}}\right)$ is plotted against the inverse absolute temperature on semilogarithmic co-ordinates, it provides the activation energy for diffusion of moisture during drying.

From the semi-theoretical equation as shown in equation (3), it may be noted that the drying rate constant, $\mathrm{m}$ is a function of the square of thickness at a given diffusion coefficient, as:

$m=\frac{\pi^{2} D_{e}}{L^{2}}$

This can be represented as:

$m=\pi^{2} \mathrm{D}_{e}(\mathrm{~L})^{-2}=\mathrm{A}(\mathrm{L})^{-\mathrm{n}}$

where, $A=\pi^{2} D_{e}$

$$
\mathrm{n}=2
$$

The above relationship shows that if external resistance due to thickness to mass transfer is negligible and if simultaneous heat and mass transfer effects are taken into account, the theoretical value of the exponent of the power law equation should be 2 . But the above conditions are not always satisfied (Islam, 1980; Mavroudis et al., 1998).

\section{Results and Discussion}

The study contains two sections: mechanical drying of green banana and development of chips from the mixture of dehydrated green banana powder and potato powder. The first section provides the drying kinetics representing the mechanical dehydration of green banana and the second section assesses the utilization of the flour produced from those green bananas.

\subsection{Effect of drying parameters}

\subsubsection{Effect of loading density on drying time of green banana}


To determine the effect of loading density in terms of sample thickness on drying time, samples of 4,6 and $8 \mathrm{~kg} / \mathrm{m}^{2}$ (corresponding thickness of $5,7.5$ and $10 \mathrm{~mm}$, respectively) were dried at $65^{\circ} \mathrm{C}$ dry bulb temperature and at $3 \pm 0.5 \%$ relative humidity in a cabinet dryer.

The results were analysed using Eq. (3) and the following regression equations were developed.

$$
\begin{aligned}
& M R=1.101 \mathrm{e}^{-0.2917 t}\left(\text { for } 4 \mathrm{kgm}^{-2}\right) \\
& M R=1.048 \mathrm{e}^{-0.1422 \mathrm{t}}\left(\text { for } 6 \mathrm{kgm}^{-2}\right) \\
& \mathrm{MR}=1.0403 \mathrm{e}^{-0.1069 \mathrm{t}}\left(\text { for } 8 \mathrm{kgm}^{-2}\right) \\
& \text { where, } \mathrm{t}=\text { drying time, hr }
\end{aligned}
$$

The moisture ratio (MR) versus drying time, $\mathrm{t}$ were plotted on semi-logarithmic scale as shown in Fig 1. It can be seen from this figure that the moisture ratio is the lowest of the sample with the lowest loading density $\left(4 \mathrm{~kg} / \mathrm{m}^{2}\right)$ and the highest of the sample with the highest loading density $\left(8 \mathrm{~kg} / \mathrm{m}^{2}\right)$ at any specific drying time. It implies that drying rate decreases with increasing loading density. This can be attributed to the thickness of the sample as the sample with least thickness corresponds to the shortest diffusion path (for moisture) and vice versa.

\subsubsection{Effect of thickness on drying rate constant}

Drying rate constants were calculated by regression analysis for each sample thickness using Eq. (6) and drying rate constants were plotted against sample thickness on semilogarithmic coordinates (Fig. 2). The relationships are represented by the following power law equations:

$$
\begin{aligned}
& \mathrm{m}=0.05 \mathrm{~L}^{-1.4702}\left(\text { for } 65^{\circ} \mathrm{C}\right) \\
& \left.\mathrm{m}=0.0476 \mathrm{~L}^{-1.5217} \text { (for } 60^{\circ} \mathrm{C}\right) \\
& \left.\mathrm{m}=0.0151 \mathrm{~L}^{-1.0495} \text { (for } 55^{\circ} \mathrm{C}\right) \\
& \text { When, } \mathrm{m}=\text { drying rate constant }\left(\mathrm{min}^{-1}\right. \text { ) } \\
& \mathrm{L}=\text { sample thickness }(\mathrm{mm})
\end{aligned}
$$

From Fig 2, it can be seen that thickness affects the drying time and as thickness of the samples increases, the drying time to achieve a desired moisture ratio also increases with resultant decrease in drying rate constants. It corroborates the findings represented by Fig 1, and suggests that to achieve a desired moisture ratio, the sample with $5 \mathrm{~mm}$ thickness $\left(4 \mathrm{~kg} / \mathrm{m}^{2}\right.$ loading density) requires much lower time compared to those with $10 \mathrm{~mm}$ thickness $\left(8 \mathrm{~kg} / \mathrm{m}^{2}\right.$ loading density)

Through regression analysis, it was found that the value of 'n' were $1.5217,1.4702$ and 1.0495 for 65,60 and $55^{\circ} \mathrm{C}$. All of these values are less than 2 which confirm that there was significant external resistance to mass transfer despite of dominance of the internal mass transfer resistance. The ' $n$ ' values obtained in this investigation were similar to the one reported by Islam (1984), as these authors obtained $n=1.7$ in case of potato dehydration. Islam suggested that although the 'n' value are primarily affected by the sample thickness the product structure and compositions, and simultaneous heat and mass transfer effects also play an important role in this regard even when the external resistance to heat transfer is insignificant.

\subsubsection{Effect of temperature on drying time}

To determine the effect of drying temperature on drying time, $5 \mathrm{~mm}$ samples $\left(4 \mathrm{~kg} / \mathrm{m}^{2}\right.$ loading density) were dried at 55,60 and $65^{\circ} \mathrm{C}$ dry bulb temperatures and the MR values were plotted against drying time (t) on semi-log co-ordinates (Fig. 3). Subsequently, the following regression equations were obtained.

$$
\begin{aligned}
& M R=1.104 \mathrm{e}^{-0.2917 t}\left(\text { for } 65^{\circ} \mathrm{C}\right) \\
& M R=1.1034 \mathrm{e}^{-0.2605 t}\left(\text { for } 60^{\circ} \mathrm{C}\right) \\
& M R=1.0553 \mathrm{e}^{-0.1896 t}\left(\text { for } 55^{\circ} \mathrm{C}\right)
\end{aligned}
$$

Fig. 3 shows that when dry bulb temperature increased, gradient or slope of the figure also increased with respect to period of drying. This implies that the higher drying rate constant was resulted from the higher amount of water removal with increasing drying temperature from 55 to $65^{\circ} \mathrm{C}$. Because of this higher moisture removal rate, the time to reach a desired/specific moisture ratio decreases. For example, the drying time required to reach $\mathrm{MR}=0.5$ was 240 minutes at $65^{\circ} \mathrm{C}$ while it was 350 minutes at $55^{\circ} \mathrm{C}$. 


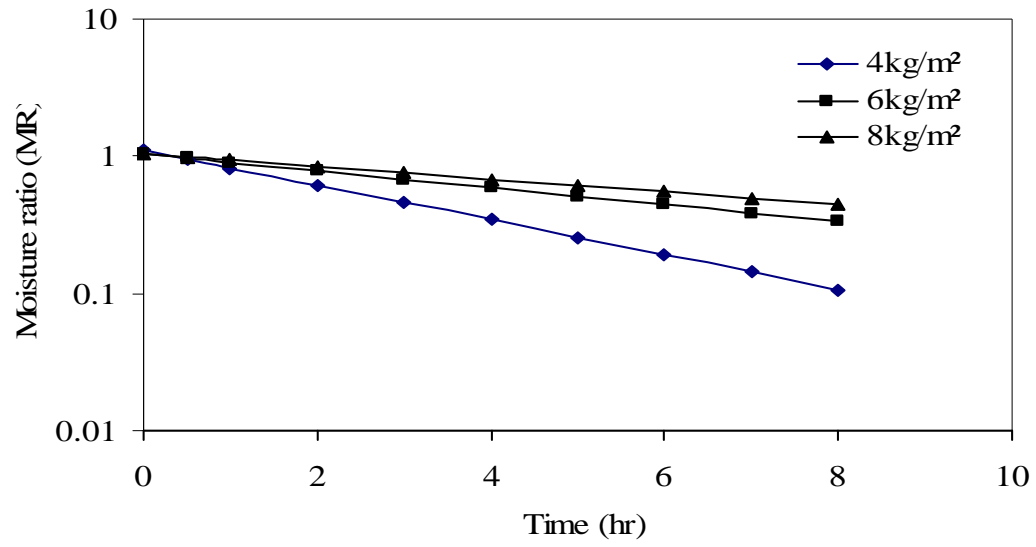

Fig. 1. Effect of loading density on drying rate of green banana at $65^{\circ} \mathrm{C}$.

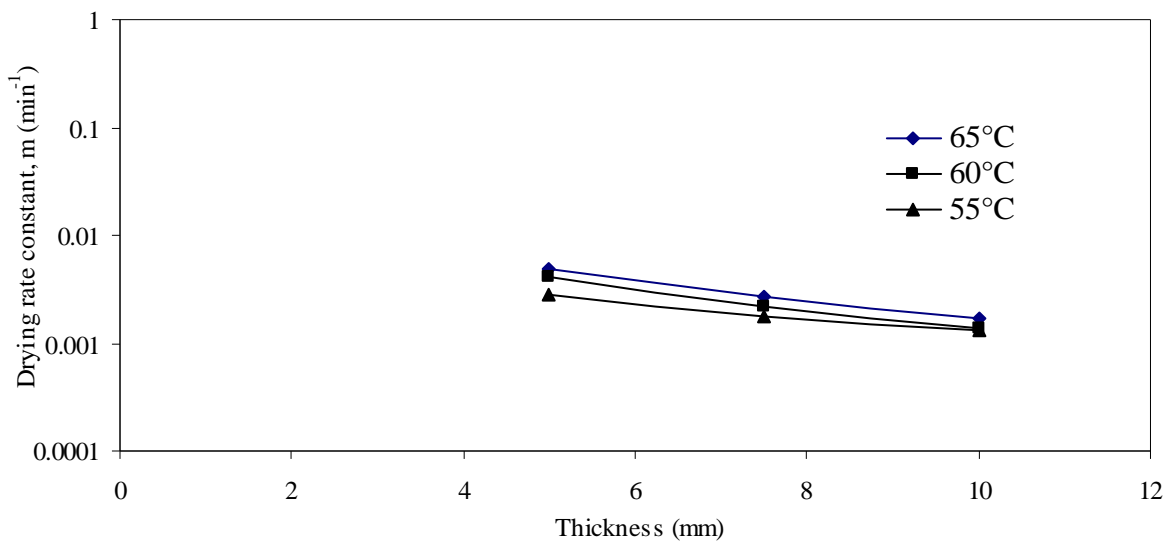

Fig. 2. Influence of thickness on drying rate constant (m) at different temperature. 


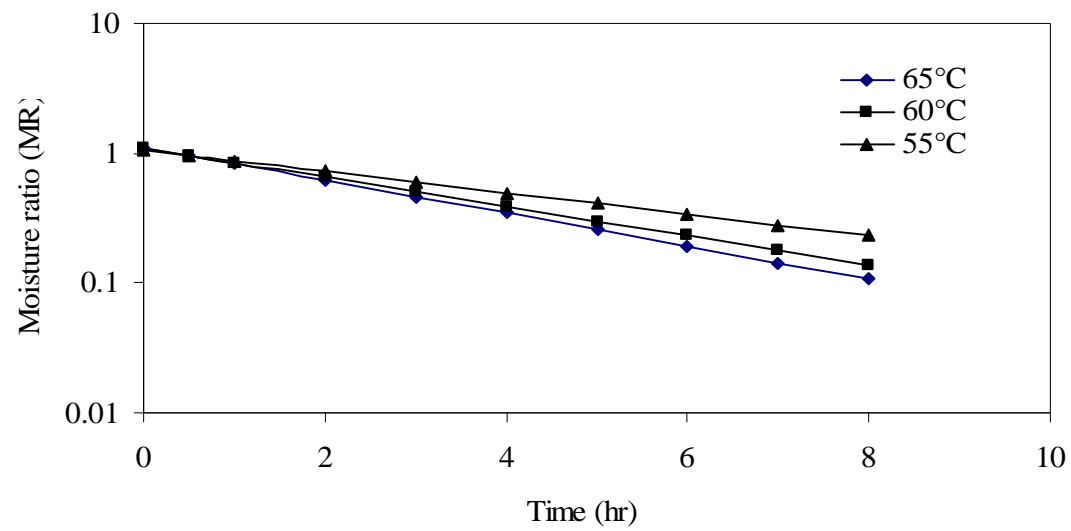

Fig. 3. Effect of drying air temperature on drying rate of green banana at $4 \mathrm{~kg} / \mathrm{m}^{2}$ loading density.

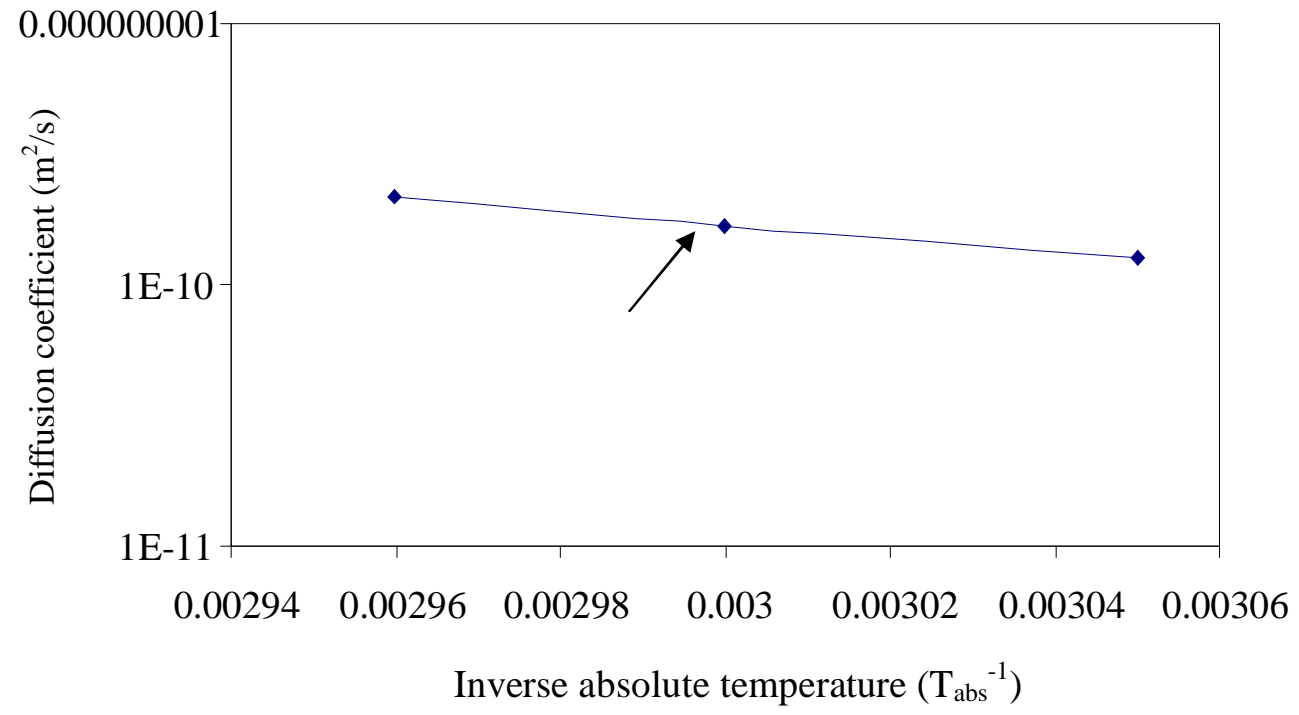

Fig. 4. Effect of drying temperature on diffusion coefficient $\left(D_{e}\right)$ of $5 \mathrm{~mm}$ thick green banana slices in a mechanical dryer. 
This is due to the fact that the moisture diffusivity increases with the increase in temperatures and also that the relative vapour pressure (relative humidity) of water decreases with the increase in temperature. The deficit in water vapour (i.e., lower relative humidity of drying medium) is a strong driving force in drying processes (Methakhup et al., 2004; Prabhanjan et al., 1995). However, for thermally sensitive samples, as used in this study, excessively high temperatures are not suggested due to nutrient loss and possibility of case hardening as a result of too strong vapour pressure difference.

\subsubsection{Diffusion coefficient and activation energy}

From the drying rate constants, the diffusion coefficients were calculated. Effective moisture diffusivity $\left(D_{e}\right)$ versus inverse absolute temperatures $\left(\mathrm{T}_{\mathrm{abs}}{ }^{-1}\right)$ was plotted on a semilogarithmic co-ordinate and regression lines were drawn. The effective moisture diffusivity increased with increasing drying temperature. The highest and the lowest diffusivity values were $2.19 \times 10^{-10} \mathrm{~m}^{2} / \mathrm{sec}$ and $1.25 \times 10^{-10} \mathrm{~m}^{2} / \mathrm{sec}$ at $65^{\circ} \mathrm{C}$ and $55^{\circ} \mathrm{C}$ respectively which agreed to the findings of other researches (Roberts et al., 2008). From the slope of the resultant straight line (Fig. 4), activation energy ( $E_{a}$ ) for diffusion of water of the green banana was calculated to be $51.21 \mathrm{KJ} / \mathrm{mole}$ which was higher than that for potato $(32.24 \mathrm{KJ} / \mathrm{mole})$ (Islam, 1984), pineapple (35.17 KJ/mole) (Uddin and Islam, 1985), and grape seeds $(30.45 \mathrm{KJ} / \mathrm{mole})$ (Roberts et al., 2008). The differences in activation energy values can be attributed to the differences in chemical composition and cellular structure (Islam, 1980). The dependence of moisture diffusivity on absolute temperature was calculated using equation (5):

$$
D_{e}=0.01751 e^{-6152.7 T_{a b s}^{-1}}
$$

Where, $D_{\mathrm{e}}=$ diffusion co-efficient $\left(\mathrm{m}^{2} / \mathrm{sec}\right)$

\subsection{Chemical analysis}

\subsubsection{Chemical composition of potato powder and green banana powder}

Both potato flour and green banana flour are excellent sources of carbohydrate, upon which their functional characteristics and applications depend. In addition, green banana flour is rich in dietary fiber and ash content (Table 1). Ash content reflects the presence of minerals. According to Morton (1987), green banana flour is well-off calcium, potassium, iron and phosphorus. On the other hand, potato flour is richer in protein and vitamin $\mathrm{C}$ content. Calculated nutrient compositions of green banana flour and potato flour agreed with the works of many researchers (Morton, 1987; Kulkarni et al., 1996).

\subsubsection{Chemical composition of potato powder and green banana powder mixed chips}

The chips samples were fried at pre-fixed temperature and time to reach desired final moisture content of 2 to $3 \%$ (wet basis). From the analyses it was observed that the percentage of ash, fat, total carbohydrate and dietary fiber increased while protein, vitamin $\mathrm{C}$ and calorie content decreased gradually with the increment of green banana powder in chips formulation (Table 2). The loss of vitamin $\mathrm{C}$ can be attributed to the frying temperature. Although the amount of fat content in the raw powders was less (near $1 \%$ ), it increased remarkably in the final chips to a maximum value of $36.90 \pm 1.2 \%$ as the frying was carried out in soybean oil.

Statistical analyses also revealed that amount of ash, fat, total carbohydrate and dietary fiber were increased significantly $(p<0.05)$ with the increment of green banana flour in chips formulation (Table 2). This result confirms that the incorporation of green banana flour in the potato chips enhances the nutritive value (including minerals) of the latter. 
Table 1. Nutritional values of the potato powder and green banana powder (per $100 \mathrm{~g}$ powder)

\begin{tabular}{lccccccc}
\hline Powder & Moisture $(\mathrm{g})$ & Protein $(\mathrm{g})$ & Fat $(\mathrm{g})$ & Ash $(\mathrm{g})$ & $\begin{array}{c}\text { Total } \\
\text { carbohydrate }(\mathrm{g})\end{array}$ & $\begin{array}{c}\text { Crude fiber } \\
(\mathrm{g})\end{array}$ & Vitamin C $(\mathrm{mg} / 100 \mathrm{~g})$ \\
\hline $\begin{array}{l}\text { Potato powder } \\
\begin{array}{l}\text { Green banana } \\
\text { powder }\end{array}\end{array}$ & $9.22 \pm 0.25$ & $10.88 \pm 0.3$ & $1.1 \pm 0.04$ & $2.49 \pm 0.45$ & $74.5 \pm 1.22$ & $1.64 \pm 0.26$ & $41 \pm 0.8$ \\
\hline
\end{tabular}

All compositions were average of two analyses from each three replicates.

Table 2. Composition of chips from potato and green banana powder (per 100g chips sample)

\begin{tabular}{|c|c|c|c|c|c|c|c|}
\hline $\begin{array}{c}\text { Chips } \\
\text { sample }\end{array}$ & \multicolumn{7}{|c|}{ Nutrient Components } \\
\hline${ }^{\mathrm{b}} 111$ & $1.52 \pm 0.009 \mathrm{~d}$ & $4.83 \pm 0.32 b$ & $35.73 \pm 1.4 \mathrm{~d}$ & $52.58 \pm 1.28 \mathrm{e}$ & $5.96 \pm 0.08 \mathrm{e}$ & $22.33 \pm 1.18 b$ & $530 \pm 3 b$ \\
\hline${ }^{c} 222$ & $1.62 \pm 0.1 \mathrm{c}$ & $4.1 \pm 0.66 c$ & $36.1 \pm 1.7 \mathrm{~cd}$ & $52.7 \pm 1.66 \mathrm{~d}$ & $6.03 \pm 0.06 \mathrm{~d}$ & $18.47 \pm 0.9 \mathrm{c}$ & $527 \pm 4.5 c$ \\
\hline $\mathrm{e} 444$ & $1.72 \pm 0.06 \mathrm{ab}$ & $2.9 \pm 0.48 \mathrm{e}$ & $36.6 \pm 1.3 \mathrm{ab}$ & $54.0 \pm 1.82 \mathrm{~b}$ & $6.83 \pm 0.1 b$ & $13.8 \pm 1.0 \mathrm{e}$ & $525 \pm 4 c$ \\
\hline $\mathrm{f}_{555}$ & $1.77 \pm 0.07 \mathrm{a}$ & $2.56 \pm 0.42 \mathrm{f}$ & $36.90 \pm 1.2 \mathrm{a}$ & $54.47 \pm 1.11 \mathrm{a}$ & $7.06 \pm 0.09 \mathrm{a}$ & $10.47 \pm 0.8 \mathrm{f}$ & $521.7 \pm 3 d$ \\
\hline $\mathrm{CV}(\%)$ & 2.07 & 2.29 & 0.53 & 0.12 & 1.43 & 2.05 & 0.3 \\
\hline $\begin{array}{l}\text { LSD at } \\
5 \% \text { level }\end{array}$ & 0.056 & 0.169 & 0.337 & 0.113 & 0.160 & 0.680 & 2.781 \\
\hline
\end{tabular}

Means with the same letters within the columns are not significantly different at 5\% level.

All compositions were average of two analyses from each three replicates.

${ }^{a}$ Chips sample prepared without mixing green banana flour in the potato chips formulation.

Chips sample prepared from potato flour: green banana flour ${ }^{\mathrm{b}}(70: 30) ;{ }^{\mathrm{c}}(60: 40) ;{ }^{\mathrm{d}}(50: 50) ;^{\mathrm{e}}(40: 60){ }^{\mathrm{f}}(30: 70)$. 


\section{Conclusions}

The study revealed that appropriate conditions of dehydration would enhance the drying performance of mechanical dryer. In case of temperature setting, $65^{\circ} \mathrm{C}$ drying temperature is suggested to get faster drying of green banana without any irregular burning or stake burning. In case of thickness, it was found that the thinner were the slices the faster was the drying rate. Lower loading density resulted in faster drying rate than the higher ones. Activation energy $\left(\mathrm{E}_{\mathrm{a}}\right)$ for diffusion of water for green banana pieces was found to be $51.21 \mathrm{KJ} / \mathrm{mole}$. The typical moisture diffusivity values were found to be $1.25 \times 10^{-10}, 1.67 \times 10^{-10}$ and $2.19 \times 10^{-10} \mathrm{~m}^{2} / \mathrm{sec}$ at 55,60 and $65^{\circ} \mathrm{C}$ respectively. Addition of green banana flour has positive impact on the nutritive values of the potato chips. It enhanced the fiber and mineral content of the chips.

\section{References}

Belghit, A., Kouhila, M. and Boutaleb, B.C. 2000. Experimental study of drying kinetics by forced convection of aromatic plants. Journal of Energy Conversion and Management, 41:1303-1321.

Bello-Perez, L. A., Pano de Leon, Y., AgamaAcevedo, E. and Paredes-Lopez, O. 1999. Isolation and partial characterization of amaranth and banana starches. Starch/Starke, 50(10): 409-413.

Choo, C. L. 2007. Utilization of matured green banana powder and oat beta glucan as fiber ingredients in noodles. Master of Science thesis, University of Sains Malaysia.

Conway, J. M., Castaigne, F., Picard, G. and Voxan, X. 1983. Mass transfer considerations in the osmotic dehydration of apples. Canadian Institute of Food Science and Technology, 16: 25-29.

Cordenunsi, B. R. and Lajolo, F. M. 1995. Starch breakdown during banana ripening: sucrose synthase and sucrose phosphate synthase. Journal of Agriculture and Food Chemistry, 43:347-351.
FAO, 2003. Production and Marketing of banana. Food and Agricultural Organization of the United Nations, Rome, Italy.

Farid, H. A. R. July 2003. Effect of various treatments on banana ripening. Ahfad Journal, http://www.thefreelibrary.com, a0111026043.

Haque, M. A. 2008. Banana: Crop botany, Culture and Uses. Bangla Academy Press, Dhaka, Bangladesh, 35 p.

Ibrahim, M., Sopian, K. and Daud, W. R. W. 2009. Study of the Drying Kinetics of Lemon Grass. American Journal of Applied Sciences, 6 (6):1070-1075.

Islam, M. N. 1980. Use of solar energy for development of shelf-stable potato products. PhD thesis, The Royal Veterinary and Agricultural University, Copenhagen, Denmark.

Islam, M. N. 1984. Kinetic analysis of air drying of potato: traditional and improved methods. Journal of Agricultural Engineering, Institute of Engineers Bangladesh, 12:3-11.

Kayisu, K., Hood, L. F. and Vansoest, P. J. 1981. Characterization of starch and fiber of banana fruit. Journal of Food Science, 46:1885-90.

Kaymak-ertekin, F. and Cakaloz, T. 1996. Osmotic dehydration of peas: influence of process variables on mass transfer. Journal of Food Processing and Preservation, 20, 87-104.

Kiranoudis, C. T., Maroulis, Z. B, Tsami, E. and Marinos-Kouris, D. 1997. Drying kinetics of some fruits. Drying Technology, 15:1399-1418.

Krokida, M., Karathanos, V., Maroulis, Z. and Marinos-Kouris, D. 2003. Drying kinetics of some vegetables. Journal of Food Engineering, 59:391-403. 
Kulkarni, K. D., Govinden, N. and Kulkarni, D. 1996. Production and use of raw potato powder in Mauritian traditional foods. The United Nations University Press, Food and Nutrition Bulletin, 17(2):148-156.

Lewis, D. A. and Lewis, V. M. August 1995. Process for preparing no or low fat potato chips and straws.

United State Patent number 5441758, http://www.freepatentsonline.com/5441758. html.

Mavroudis, N. E., Gekas, V. and Sjöholm, I. 1998. Osmotic dehydration of apples effects of agitation and raw material characteristics. Journal of Food Engineering, 35:191-209.

Methakhup, S., Chiewchan, N. and Devahastin, S. 2004. Effects of drying methods and conditions on drying kinetics and quality of Indian gooseberry flake. Journal of Food Engineering, 38:579-587.

Morton, J. F. 1987. Fruits of warm climates. In Proceedings of the Sixth National Symposium on Creating Markets for Economic Development of New Crops and New Uses, Purdue University, Miami, USA, 29-46.

Prabhanjan, D., Ramaswamy, H. and Raghavan, G. 1995. Microwave-assisted convective air drying of thin layer carrots. Journal of Food Engineering, 25:283-293.

Rabbani, G. H., Ahmed, S., Hossain, M. I., Islam, R., Marni, F., Akhtar, M. and Majid, N. 2009. Green banana reduces clinical severity of childhood shigellosis: a doubleblind, randomized, controlled clinical trial. The Pediatric Infectious Disease Journal, 28(5):420-425.
Rangana, S. 1992. Handbook of Analysis and Quality Control for Fruit and Vegetable Products; Second edition; Tata McGraw Hill Pub. Co. Ltd.; New Delhi 50-152 pp.

Reddy, G. V. and Das, H. 1993. Kinetics of Deep-fat-frying potato and optimization of process variables. Journal of Food Science, 30(2):105-108.

Roberts, J. S., Kidd, D. R. and Padilla-Zakour, O. 2008. Drying kinetics of grape seeds. Journal of Food Engineering, 89:460-465.

Sablani, S. S., Rahman, M. S. and Al-Habsi, N. 2000. Moisture diffusivity in foods - an overview. Drying Technology in Agriculture and Food Sciences; Mujumdar, A.S., Eds.; Science Publishers Inc.; Enfield, NH. 35-59 pp.

Sogi, D. S., Shivhare, U. S., Garg, S. K. and Bawa, A.S. 2003. Water sorption isotherm and drying characteristics of tomato seeds. Biosystems Engineering, 84(3):297-301.

Suarez, C., Viollaz, P. and Chirife, J. 1980. Diffusional analysis of air drying of grain sorghum. Journal of Food Technology, 15:523-531.

Suntharalingam, S. and Ravindran, G.1993. Physical and biochemical properties of green banana powder. Journal of Plant Foods for Human Nutrition, 43(1):19-27.

Uddin, M. B. and Islam, M. N. 1985. Development of shelf stable pineapple products by different methods of drying. Journal of Agricultural Engineering, Institute of Engineers Bangladesh, 13(1):513.

Vaccarezza, L. M., Lombardi, J. L. and Chirife, J. 1974. Heat transfer effects on drying rate of food dehydration. Canadian Journal of Chemical Engineering, 52:576-579. 